\title{
STRATEGI GURU PPKN DALAM MENGANTISIPASI KEKERASAN PADA SISWA
}

\author{
Aryanti Dwi Untari ${ }^{1}$ Elly Setiawati ${ }^{2}$ \\ Universitas Banten Jaya \\ Serang, Indonesia \\ aryantidwiuntari@unbaja.ac.id ${ }^{1}$ ellysetiawati95@gmail.com²
}

\begin{abstract}
This study aims to determine the strategies of teachers, especially teachers in anticipating violence against students. One of the phenomena that has caught the attention of the world of education today is violence that occurs in the school environment. Violence between students will certainly affect the learning conditions in the classroom. Students who experience physical and verbal abuse will certainly feel psychologically disturbed. Disturbed psychological conditions will also trigger disruption of the enthusiasm and interest of students in learning.The role of the teacher is very necessary to reduce even if it can eliminate the condition. Based on these problems, this study aims to: (1) determine the role of PPKn teachers in anticipating violence against students; (2). Knowing the obstacles of PPKn teachers in anticipating violence against students; (3). know what efforts are made by the PPKn teacher in anticipating violence against students. This research uses a descriptive method with a qualitative approach. Data collection techniques using observations, interviews and documentation conducted in the environment of SMK 17 Serang City. The research results obtained in the field show that the PPKn teacher's strategy in anticipating violence in children is to provide understanding related to norms about diversity, fostering character to care for each other, carrying out positive activities in the school environment such as extracurricular or social activities. others in the classroom environment and broadly in the school, and invites parents to control the activities of children in their environment.the strategy carried out by the teachers is done as an effort to prevent and deal with violence against students.
\end{abstract}

Keywords: Teacher Strategies, Prevention of Violence, Violence On Children

\section{PENDAHULUAN}

Pendidikan adalah usaha sadar dan terencana untuk mewujudkan suasana belajar dan proses pembelajaran agar peserta didik secara aktif mengembangkan potensi dirinya untuk memiliki kekuatan spiritual keagamaan, pengendalian diri, kepribadian, kecerdasan, akhlak mulia serta keterampilan yang diperlukan dirinya, masyarakat, bangsa dan negara (UndangUndang Nomor 20 Tahun 2003). Salah satu faktor penentu keberhasilan proses pendidikan adalah guru. Roqib dan Nurfuadi (2009: 22) mengartikan "Guru sebagai orang yang bertugas mencerdaskan kehidupan bangsa dalam semua aspeknya, baik spiritual, emosional, intelektual, fisikal, finansial, maupun aspek lainnya". Guru sebagai abdi negara memiliki peran sebagai pengajar, pendidik, pembimbing, fasilitator, dan motivator bagi peserta didik. Guru dituntut untuk menjalankan perannya dengan penuh tanggung jawab 
agar dapat meningkatkan kualitas peserta didik agar mampu hidup di masa yang akan datang. Menurut Sukardjo dan Ukim Komarudin (2009) mengajar merupakan sebagian kecil dari mendidik. Mengajar dimaknai sebagai penyajian bahan ajar berupa pengetahuan, nilai dan deskripsi keterampilan kepada seseorang dengan maksud agar pengetahuan yang diperlukan dapat meningkatkan intelegensinya secara intelektual. Sedangkan mendidik merupakan proses educating yang dimulai dalam relasi pergaulan manusia, termasuk kualitas belajar dan mendidik diri sendiri. Mendidik di dasarkan pada tindakan memanusiakan manusia dalam interaksi internal yang menjadi landasan dari relasi pendidikan dan interaksi edukatif dalam arti luas.

Mulyasa (Roqib dan Nurfuadi, 2009:104) menyebutkan lima peran dan fungsi Guru yaitu sebagai pendidik dan pengajar, anggota masyarakat, pemimpin, administrator, dan pengelola pembelajaran. Sebagai pendidik dan pengajar, Guru harus memiliki pengetahuan luas baik itu teori pendidikan serta menguasai kurikulum dan metodologi pembelajaran. Sebagai anggota masyarakat Guru harus menguasai psikologi sosial, memiliki pengetahuan tentang hubungan antar manusia, dan memiliki keterampilan membina kelompok. Guru sebagai pemimpin harus memiliki kepribadian, menguasai ilmu kepemimpinan, prinsip hubungan antar manusia, serta meguasai berbagai aspek kegiatan organisasi sekolah. Sebagai administrator seorang Guru dihadapkan pada tugas administrasi yang harus dikerjakan di sekolah sehingga harus memiliki pribadi yang jujur, teliti, rajin, serta memahami strategi dan manajemen pendidikan. Sedangkan Guru sebagai pengelola pembelajaran diharapkan mampu menguasai berbagai metode pembelajaran dan memahami situasi belajar mengajar di dalam maupun di luar kelas. Guru merupakan figur manusia yang memiliki peranan penting dalam pendidikan.

Guru sebagai ujung tombak dalam pelaksanaan Pendidikan merupakan pihak yang sangat berpengaruh dalam proses Pendidikan. Guru harus memiliki kualifikasi yang memadai dan memiliki kompetensi untuk dapat melaksanakan perannya. Adapun peran seorang guru menurut Amri, S. (2013, hlm. 30) Guru memiliki peran dalam aktivitas pembelajaran, yaitu sebagai berikut:

\section{Korektor}

Guru menilai dan mengoreksi semua hasil belajar, sikap, tingkah, dan perbuatan siswa baik di sekolah maupun di luar sekolah evaluator. 
2. Inspirator

Guru memberikan inspirasi kepada siswa mengenai cara belajar yang baik.

\section{Informator}

Guru memberikan informasi yang baik dan efektif mengenai materi yang telah di programkan serta informasi perkembangan ilmu pengetahuan dan teknologi.

4. Organisator

Guru berperan mengelola berbagai kegiatan akademik baik intrakurikuler maupun ekstrakurikuler sehingga tercapai efektivitas dan efisiensi anak didik.

5. Motivator

Guru dituntut untuk dapat mendorong anak didiknya agar senantiasa memiliki motivasi tinggi dan aktif belajar.

6. Inisiator

Guru menjadi pencetus ide-ide kemajuan dalam pendidikan dan pengajaran

7. Fasilitator

Guru hendaknya dapat menyediakan fasilitas yang memungkinkan anak didik dapat belajar secara optimal.

8. Pembimbing

Guru memberikan bimbingan kepada anak didiknya dalam menghadapi tantangan maupun kesulitan belajar.

9. Demonstrator
Guru dituntut untuk dapat memperagakan apa yang diajarkan secara didaktis, sehingga anak didik dapat memahami pelajaran secara optimal.

10. Pengelola kelas

Guru hendaknya dapat mengelola kelas dengan baik, karena kelas adalah tempat berhimpun guru dan siswa

11. Mediator

Guru dapat berperan sebagai penyedia media dan penengah dalam proses pembelajaran peserta didik.

12. Supervisor

Guru hendaknya dapat membantu, memperbaiki dan menilai secara kritis proses pembelajaran yang dilakukan sehingga dapat optimal

13. Evaluator

Guru dituntut untuk mampu menilai produk pembelajaran serta proses pembelajaran.

Salah satu fenomena yang terjadi dalam dunia pendidikan ialah terdapat kekerasan yang terjadi di lingkungan sekolah. Beberapa kasus kekerasan yang terjadi dilakukan oleh siswa, baik antara siswa dan siswa, maupun siswa dengan guru.

Berdasarkan pemantauan di media massa, sampai bulan Oktober, sepanjang 2019 Komisi Perlindungan Anak Indonesia menemukan 21 kasus kekerasan fisik di lembaga pendidikan. Kejadian tersebut dilakukan baik terhadap siswa terhadap siswa maupun guru dengan siswa. Retno 
Listyarti, Komisioner Bidang Pendidikan KPAI menemukan kekerasan fisik yang terjadi di SD/MI sebanyak tujuh kasus, di SMP sebanyak lima kasus, di SMA/MA sebanyak tiga kasus dan SMK ada empat kasus. "Dari 21 kasus tersebut, siswa korban kekerasan mencapai 65 anak " (Retno, Health Liputan6.com pada Kamis $31 / 10 / 2019)$.

Kekerasan pada anak dapat dimanifestasikan dalam berbagai bentuk (Swearer, dkk: 2009; Duncan, 2007; Lee, 2004; dan Paglicci, dkk.; 2002). Bentukbentuk tersebut antara lain kekerasan fisik, kekerasan psikologis, kekerasan sosial atau kekerasan verbal, kekerasan seksual serta penelantaran dan perlakuan buruk berupa pembiaran, tidak merawat, dan meninggalkan anak dalam situasi yang tidak berdaya.

Perilaku kekerasan tidak mungkin terjadi dengan tiba-tiba. Seseorang menampilkan perilaku itu merupakan hasil belajar juga, baik secara langsung maupun tidak langsung. Untuk itu, pendidikan harus peduli terhadap upaya untuk mencegah perilaku kekerasan secara dini melalui berbagai program edukasi mengenai kekerasan pada siswa. Program edukasi kekerasan ini dapat dilakukan pada tingkat sekolah, guru, kegiatan kelas, kegiatan ekstrakurikuler sekolah atau program pelatihan khusus (Shafii dan Shafii, 2001)
Salah satu kekerasan yang terjadi di sekolah adalah bullying. Menurut Wiyani,N (2012, hlm.5) School bullying adalah perlakuan tidak menyenangkan yang dialami siswa di sekolah. Pelaku school bullying ada umumnya teman sebagai, siswa yang lebih senior, atau bahkan guru. Istilah Bullying berasal dari Bahasa Inggris yakni kata "bull" yang berarti "banteng" yang suka menanduk. Pihak pelaku bullying biasa disebut bully. (Sejiwa, 2008, Hlm. 2)

Kegunaan edukasi kekerasan terhadap siswa (Moore dan Minton, 2005; Fontaine, 1991) adalah menanamkan pengertian bahwa rasa aman adalah hak dan milik semua orang; menyadarkan siswa bahwa setiap orang punya perbedaan yang harus dihormati; menyadarkan semua orang di sekolah bahwa tindakan kekerasan dalam bentuk apapun tidak dapat diterima (zero tolerance); membantu siswa mengetahui, memahami, mengenali, mengidentifikasi dan mendeskripsikan peristiwa, perilaku, dan pelaku kekerasan; membekali siswa untuk membuat keputusan strategis mengenai perilaku dan peristiwa kekerasan, baik yang terjadi pada dirinya, orang terdekat, atau orang lain; membantu siswa membentuk lingkaran orang yang mereka percayai untuk membantu di dalam penanggulangan kekerasan; dan menanamkan kepercayaan diri siswa untuk 
berpartisipasi dalam penggalangan budaya damai.

Menurut Olweuss (dalam Luciano dan Savage, 2007) Bullying adalah bentuk tindakan kekerasan (aggression) dimana seseorang diperlakukan secara negatif berulang kali. Tiga karakter dari perilaku bullying yaitu: a) ketidak seimbangan kekuatan, dimana korban tidak merasa berdaya menghadapi penyerang; b) perilaku agresif, yaitu niat untuk melukai/mengganggu; c) berulang kali, jangka waktu untuk melakukan beberapa penyerangan.

Sebagai perilaku agresif, bullying tidak bisa didiamkan dan diabaikan begitu saja. Perlu ada upaya dari bebagai pihak untuk mengatasi bullying yang terjadi di sekolah, salah satunya yaitu guru/konselor. Layanan bimbingan konseling yang dilakukan di sekolah membuat guru/konselor mengetahui banyak permasalahan yang dihadapi siswa di sekolah, termasuk permasalahan bullying.(Yenes. 2016: 1)

Terry E. Lawson (dalam Hurairah, 2007), psikiater internasional yang merumuskan definisi tentang child abuse, menyebut ada empat macam abuse, yaitu emotional abuse, verbal abuse, physical abuse, dan sexual abuse).
1. Kekerasan secara Fisik (physical abuse)

Physical abuse, terjadi ketika orang tua/pengasuh dan pelindung anak memukul anak (ketika anak sebenarnya memerlukan perhatian). Pukulan akan diingat anak itu jika kekerasan fisik itu berlangsung dalam periode tertentu. Kekerasan yang dilakukan seseorang berupa melukai bagian tubuh anak.

2. Kekerasan Emosional (emotional abuse)

Emotional abuse terjadi ketika orang tua/pengasuh dan pelindung anak setelah mengetahui anaknya meminta perhatian, mengabaikan anak itu. Ia membiarkan anak basah atau lapar karena ibu terlalu sibuk atau tidak ingin diganggu pada waktu itu. Ia boleh jadi mengabaikan kebutuhan anak untuk dipeluk atau dilindungi. Anak akan mengingat semua kekerasan emosional jika kekerasan emosional itu berlangsung konsisten. Orang tua yang secara emosional berlaku keji pada anaknya akan terusmenerus melakukan hal sama sepanjang kehidupan anak itu.

3. Kekerasan secara Verbal (verbal abuse)

Biasanya berupa perilaku verbal dimana pelaku melakukan pola komunikasi yang berisi penghinaan, ataupun kata-kata yang melecehkan 
anak. Pelaku biasanya melakukan tindakan mental abuse, menyalahkan, melabeli, atau juga mengkambinghitamkan.

4. Kekerasan Seksual (sexual abuse) Sexual abuse meliputi pemaksaan hubungan seksual yang dilakukan terhadap orang yang menetap dalam lingkup rumah tangga tersebut (seperti istri, anak dan pekerja rumah tangga). Selanjutnya dijelaskan bahwa sexual abuse adalah setiap perbuatan yang berupa pemaksaan hubungan seksual, pemaksaan hubungan seksual dengan cara tidak wajar dan atau tidak disukai, pemaksaan hubungan seksual dengan orang lain untuk tujuan komersil dan atau tujuan tertentu.

Berdasarkan data kasus pelanggaran anak pada klaster pendidikan, dapat diamati bahwa kasus pelanggaran anak mengalami peningkatan jumlah kasus yang cukup besar dari tahun ke tahun dengan dominasi jumlah kasus tertinggi ialah kasus anak korban kebijakan diantaranya anak dikeluarkan karena hamil, pungli di sekolah, penyegelan sekolah, tidak boleh ikut ujian, anak putus sekolah, drop out, dsb. Hal ini dapat dilihat pada gambar sebagai berikut:

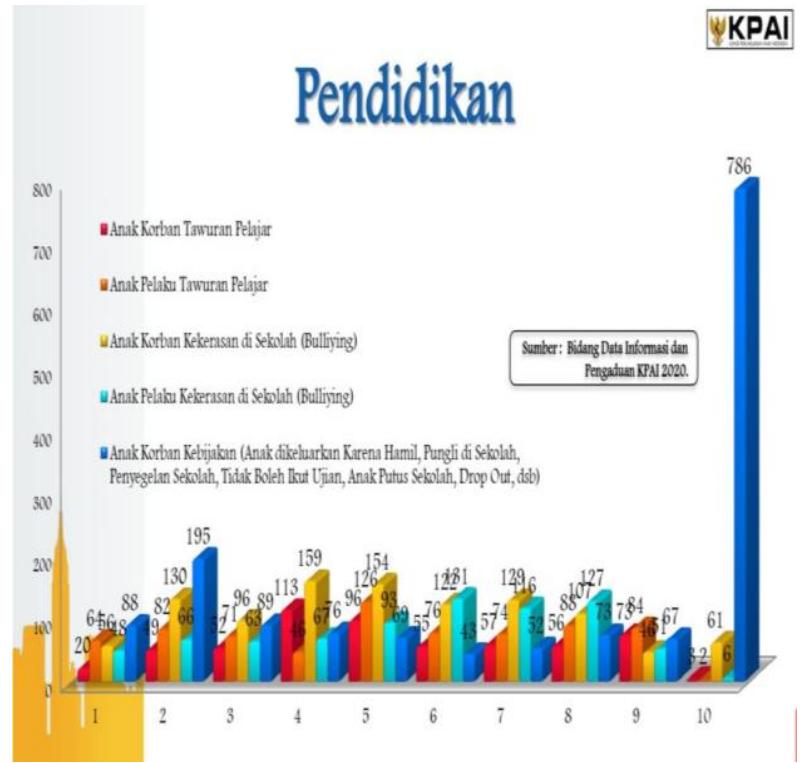

Gambar 2 diagram jenis kasus pelanggaran anak klaster pendidikan

Tindakan kekerasan anak atau pelanggaran anak pada klaster Pendidikan tentu sangat mempengaruhi proses pembelajaran dan Pendidikan nya di sekolah. Bukan hanya sekedar mempengaruhi kondisi belajar siswa di kelas tetapi juga mempengaruhi kondisi mental siswa untuk mengikuti berbagai kegiatan di sekolah baik dari segi intrakurikuler, ekstrakurikuler dan kokurikuler.

Siswa yang mengalami kekerasan fisik maupun kekerasan verbal tentunya akan merasa terganggu secara psikis. Kondisi psikis yang terganggu akan memicu terganggunya pula semangat dan minat siswa dalam belajar. Peran Guru sangat diperlukan untuk menurunkan bahkan kalau bisa menghilangkan kondisi tersebut. Sebagai pendamping, seorang Guru yang merupakan orang tua kedua di sekolah 
seharusnya memberikan solusi dan jalan keluar jika muridnya melakukan sesuatu yang sekiranya tidak benar dalam aturan norma.

Berdasarkan permasalahan di atas, penulis tertarik untuk melakukan penelitian dengan judul "Strategi Guru PPKn dalam Mengantisipasi Kekerasan Pada Siswa" .

\section{METODE PENELITIAN}

Metode yang digunakan dalam penelitian "Strategi Guru PPKn dalam Mengantisipasi Kekerasan Pada Siswa" adalah menggunakan metode kulitatif deskriftif."Penelitian kualitatif merupakan penelitian yang berlandaskan pada filsafat positivisme, yang digunakan untuk meneliti pada kondisi objek yang alamiah, (sebagai lawannya adalah eksperimen) dimana peneliti adalah sebagai instrument kunci, pengambilan sample sumber data dilakukan secara purposive dan snowball, teknik pengumpulan data dengan triangulasi (gabungan), analisis data bersifat induktif/kualitatif, dan hasil penelitian kualitatif lebih menekankan makna dari pada generalisasi". (Sugiyono, 2014: 09)

Berdasarkan pendapat ahli diatas, maka penelitian ini dilakukan untuk memusatkan perhatian pada strategi yang dilakukan guru PPKn dalam mengantisipasi kekerasan pada siswa di SMK 17 Kota Serang.
Dalam penelitian ini, peneliti menggunakan teknik pengumpulan data observasi, wawancara, dan dokumentasi. Observasi dilakukan di lingkungan SMK 17 Kota Serang dengan melakukan pengamatan terhadap aktivitas guru dan siswa di sekolah. Pengamatan ini dilakukan khususnya kepada guru PPKn dan siswa di SMK 17 Kota Serang sebagai sumber data penelitian.

Nasution (1988) menyatakan bahwa, observasi adalah dasar semua ilmu pengetahuan. Para ilmuwan hanya dapat bekerja berdasarkan data, yaitu fakta mengenai dunia kenyataan yang diperoleh melalui obsevasi.

Selain itu, peneliti mengunakan teknik wawancara, selain harus membawa instrument sebagai pedoman untuk wawancara, maka pengumpulan data juga dapat mengunakan alat bantu seperti tape recorder, gambar, brosur dan matrial lain yang dapat membantu pelaksanaan wawancara menjadi lancar, dengan narasumber guru dan siswa/siswi di SMK 17 Kota Serang.

Selanjutnya, peneliti menggunakan teknik dokumentasi dalam mengumpulkan data penelitian. Dokumentasi merupapakan catatan peristiwa yang sudah berlalu. Dokumen bisa berbentuk tulisan, gambar, atau karya-karya monumental dari seseorang. Dengan demikian, setiap penelitian tidak dapat terlepas dari 
linteratur-linteratur ilmiah sehingga kegiatan studi kepustakaan ini menjadi sangat penting.

Analisis data dilakukan sejak sebelum memasuki lapangan dan selama di lapangan. Langkah-langkah dalam menganalisis data pada penelitian kualitatif deskriptif yaitu dengan cara mereduksi data, menyajikan data (display data), dan menyimpulkan data. Langkah-langkah analisis data ini mengacu pada langkahlangkah yang dikemukakan oleh Miles and Huberman dalam Sugiyono (2014:246) adalah:

1. Reduksi data

2. Display data

3. Verification (penyimpulan data)

\section{HASIL PENELITIAN DAN PEMBAHASAN}

Guru merupakan mitra siswa dalam kegiatan belajar mengajar di sekolah. Guru yang baik ialah guru yang dapat menjadi sahabat sekaligus orang tua bagi siswanya. Guru memiliki tugas dan tanggung jawab bukan hanya sekedar mengajar, tetapi guru juga memiliki tugas dan tanggung jawab dalam mendidik dan membimbing peserta didik. Guru PPKn mengemban peran lebih dibandingkan dengan guru lain, yakni sebagai pembimbing, agen moral dan juga sebagai model bagi peserta didik. Dalam upaya mengantisipasi tindakan kekerasan yang dilakukan oleh siswa, guru memiliki tugas untuk memberi bimbingan dan pengarahan baik secara individu maupu secara kelompok.

Tindakan kekerasan bisa terjadi di seluruh dunia masyarakat. Kekerasan juga dapat muncul dengan berbagai cara dan dapat dilihat dalam tindakan yang berbeda. Kekerasan juga dinamakan dengan agresifitas. Agresifitas manusia merupakan segala bentuk perilaku yang dimaksudkan untuk menyakiti seseorang baik secara fisik maupun mental. (Berkowitz. L, hlm.4)

Kekerasan siswa seperti bullying, mengejek teman, menghina fisik seseorang mengancam, menuduh, dan melukai fisik orang lain tentu memiliki akibat yang negatif bagi siswa sendiri dan juga bagi masyarakat pada umumnya.

Bullying digambarkan sebagai bentuk dari interaksi social dimana individu yang dominan memperlihatkan perilaku agresif dengan intensitas dan juga dengan menekan individu yang kurang dominan. Bullying tidak termasuk perilaku normal anak-anak seperti perkelahian atau persaingan satu lawan satu antar saudara kandung atau antar teman sebagai karena tuntutan persaingan. (Coloroso,B. 2007, 88).

Menurut Data Komisi Perlindungan Anak Indonesia (KPAI), setiap tahun jumlah kekerasan pada anak yang dilaporkan terus 
meningkat. Data tersebut dapat dilihat dalam gambar sebagai berikut:

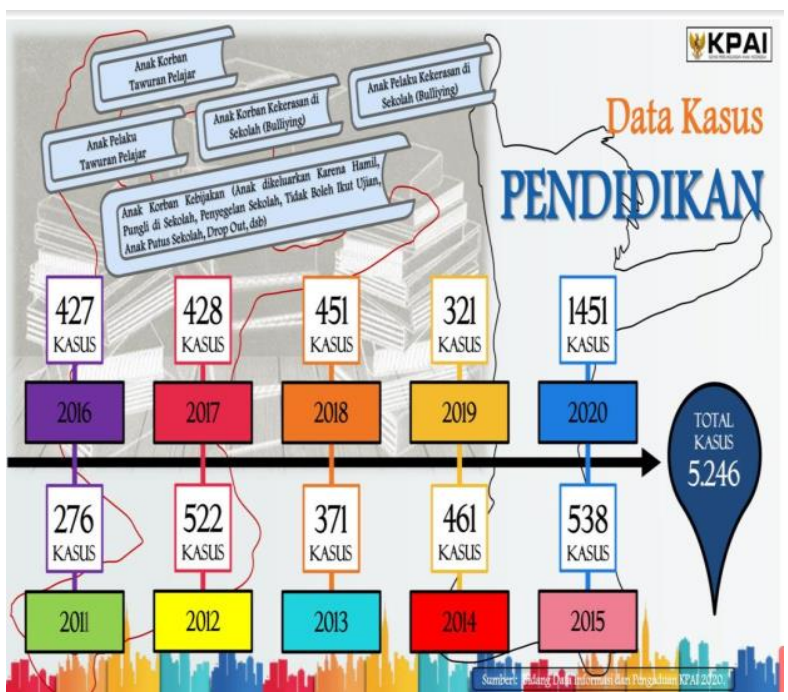

Gambar 1 Data Kasus Pelanggaran anak klaster Pendidikan

Berdasarkan gambar data kasus pendidikan diatas dapat kita lihat bahwa kasus pelanggaran anak dalam klaster pendidikan mengalami peningkatan yang sangat tinggi pada tahun 2020 yakni sebesar 1451 kasus dari kasus sebelumnya pada tahun 2019 hanya sebesar 321 kasus.

Adapun jenis kasus-kasus pelanggaran anak klaster pendidikan menurut data Komisi Perlindungan Anak Indonesia (KPAI) diantaranya ialah sebagai berikut: anak korban tawuran pelajar, anak pelaku tawuran pelajar, anak korban kekerasan di sekolah (Bullying), anak pelaku kekerasan di sekolah (bullying), anak korban kebijakan (anak dikeluarkan karena hamil, pungli di sekolah, penyegelan sekolah, tidak boleh ikut ujian, anak putus sekolah, drop out, dsb).

Dalam kurun waktu lima tahun terakhir yakni tahun 2016-2020, berdasarkan laporan pengaduan KPAI jumlah korban dan pelaku pelanggaran hak anak mencapai 23.261 orang. Presentase jumlah korban dan pelaku pelanggaran hak anak berdasarkan jenis kelamin di dominasi oleh laki-laki. Adapun presentase jumlah korban dan pelaku pelanggaran hak anak dengan jenis kelamin laki-laki sebesar $50,68 \%$ dan presentase jumlah korban dan pelaku pelanggaran hak anak dengan jenis kelamin perempuan sebesar 49,32\%.

DATA KORBAN -PELAKU PELANGGARAN HAK ANAK
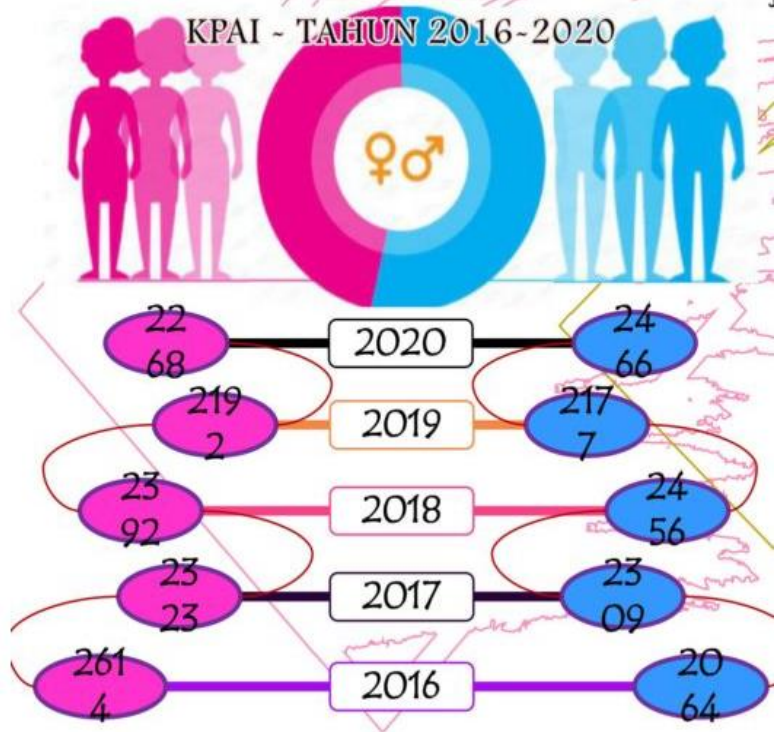

Gambar 3. Data korban-pelaku

pelanggaran hak anak berdasarkan jenis

kelamin

Dalam perspektif viktimologi, anak adalah salah satu kelompok rentan yang wajib mendapatkan perindungan dari negara. 
Artinya, anak-anak berada dalam posisi yang secara fisik dan psikis tidak mampu melindungi dirinya sendiri, karena itu negara wajib memberikan perlindungan. Bentuk perlindungan yang wajib diberikan oleh negara adalah memastikan anakanak terbebas dari praktek-praktek diskriminasi, eksploitasi dan kekerasan. (Hermawati, I dan Sodian, A, 2018. Hlm 3)

Terminologi anak menurut Pasal 1 (2) Undang-undang no 4 tahun 1979 tentang Kesejahteraan Anak adalah seseorang yang belum mencapai umur 21 tahun dan belum pernah kawin. Anak menurut Konvensi Hak Anak didefinisikan sebagai manusia yang berusia di bawah 18 tahun, kecuali berdasarkan yang berlaku bagi anak tersebut ditentukan, bahwa usia dewasa dicapai lebih awal. Sedangkan menurut Undang-undang no 3 Tahun 1997 tentang Pengadilan Anak Pasal 1 (1) disebutkan, bahwa anak adalah seseorang yang telah mencapai usia 8 (delapan) tahun tetapi belum mencapai usia 18 tahun dan belum pernah kawin. Definisi ini senada dengan UU no 39 Tahun 1999 tentang Hak Asasi Manusia yang menyebutkan, bahwa anak adalah manusia berusia di bawah 18 tahun dan belum menikah, termasuk anak dalam kandungan apabila hal tersebut adalah demi kepentingannya.

Pemerintah Indonesia telah menerbitkan beragam kebijakan untuk melindungi anak dari berbagai bentuk kekerasan. Pasca diratifikasinya Konvensi Hak Anak melalui Keputusan Presiden Nomor 36 tahun 1990, terhitung sudah 50 peraturan perundangundangan yang diterbitkan pemerintah, berupa 22 undang-undang, 9 keputusan presiden, 8 peraturan presiden, 7 peraturan pemerintah, 3 instruksi presiden, dan terakhir 1 peraturan pemerintah pengganti undang-undang yang memuat ancaman Kebiri melalui Perppu Nomor 1 Tahun 2016 tentang Perubahan Kedua atas Undang-Undang RI Nomor 2 Tahun 2002 tentang Perlindungan Anak. (Hermawati, I dan Sodian, A, 2018. Hlm. 4)

Kekerasan siswa tentu juga mempengaruhi prestasi belajar pada umumnya kekerasan siswa (bullying) juga mempengaruhi prestasi belajar siswa di sekolah.

Berdasarkan hasil wawancara dengan beberapa guru mata pelajaran PPKn, menyatakan bahwa upaya yang dilakukan untuk mengantisipasi kekerasan pada siswa dapat dilakukan dengan cara sebagai berikut:

1. Memberikan pemahaman terkait norma norma tentang keagaman

2. menumbuhkan karakter untuk saling peduli terhadap sesame

3. Melakukan kegiatan-kegiatan positif di lingkungan sekolah seperti kegiatan ekstrakurikuler atau pun pergaulan

4. lain dilingkungan kelas dan secara luas di sekolah 
Sebagaimana yang tercantum dalam

Peraturan Menteri Negara Pemberdayaan Perempuan dan perlindungan anak Republik Indonesia Nomor 02 Tahun 2010 pasal 4, Pencegahan kekerasan terhadap anak meliputi kegiatan:

a. komunikasi, informasi dan edukasi tentang pencegahan dan penanganan kekerasan terhadap anak;

b. penyusunan kebijakan pencegahan kekerasan terhadap anak;

c. partisipasi anak; dan

d. pelatihan tentang pencegahan dan penanganan kekerasan terhadap anak.

Guru memiliki peranan penting dalam mengantisipasi kekerasan yang terjadi pada siswa. Adapun peran guru PPKn $\begin{array}{lllll}\text { SMK } & 17 & \text { Kota serang dalam }\end{array}$ mengantisipasi kekerasan pada siswa dapat dilihat sebagai berikut:

1. Memiliki keahlian khusus dalam membimbing Guru PPKn di SMK 17 kota serang membimbing siswa melalui pembimbingan sikap, tingkah lakunya diarahkan pada kegiatan yang melatih kedisiplinan seperti ekstrakurikuler, tadarus di pagi hari, sholat berjamaah, berangkat tepat waktu dan lainnya.

2. Berperan sebagai agen moral Guru PPKn di SMK 17 kota serang dalam melaksanakan peran sebagai agen moral, melalui penanaman nilai-nilai moral terhadap siswa di sekolah.
Penanaman nilai moral di SMK 17 Kota Serang terhadap siswa di lakukan di dalam kelas dengan mengintegasikan materi yang diajarkan, misalnya nilai kesederhaan dan nilai demokratis. Penanaman nilai-nilai moral terhadap siswa dengan pemberian contoh yang nyata misalnya, menggunakan bahasa yang sopan, menghargai pendapat orang lain dan tidak memaksakan kehendak dalam musyawarah.

3. Berperan sebagai model Guru PPKn di SMK 17 kota serang dalam melaksanakan peran sebagai model, seorang guru memberikan suri tauladan yang dapat ditiru oleh siswa seperti menunjukkan sikap dan perilaku positif, bertutur kata sopan dan baik, dan berpakaian sopan. Guru PPKn di SMK 17 Kota Serang terus berupaya menjadi suri tauladan yang baik serta memberikan contoh yang baik kepada siswa agar siswa dapat berperilaku dengan baik pula sehingga terhindar dari tindakan kekerasan.

4. Berperan sebagai komunikator Guru PPKn di SMK 17 kota serang dalam melaksanakan perannnya sebagai komunikator dengan menjadi sahabat dan memberi nasihat terhadap siswa yang mengalami kesulitan. Nasihat merupakan salah satu teknik 
bimbingan yang dapat diberikan guru terhadap siswa yang mengalami masalah atau kesulitan. Guru PPKn dalam memberikan nasihat hendaknya memperhatikan hal-hal sebagai berikut. (a) berdasarkan masalah atau kesulitan yang dihadapi oleh siswa, (b) nasihat yang diberikan bersifat alternatif yang dapat dipilih siswa, (c) penentuan keputusan diserahkan kepada siswa, alternatif mana yang diambil dan (d) siswa mau dan mampu mempertanggungjawabkan keputusan yang diambil.

5. Mengajark orang tua untuk mengawasi kegiatan anak di lingkungan rumahnya.

Komunikasi antara guru kepada siswa sangat dibutuhkan siswa dalam mengatasi segala permasalahan yang dihadapi oleh siswa baik saat mengalami kesulitan dalam proses pembelajaran maupun dalam pergaulan di lingkungan sekolah. Komunikasi yang baik antara guru dan siswa ini jika dapat terjalin dengan baik maka akan mencegah terjadinya kekerasan pada siswa. Berdasarkan hasil temuan di lapangan, Pemberian bimbingan yang dilakukan guru PPKn di SMK 17 kota serang pada siswa dilakukan dua pendekatan yaitu:

1. Pendekatan individu atau langsung, yaitu bimbingan yang diberikan secara pribadi pada siswa yang bermasalah. Melalui percakapan mungungkap kesulitan siswa dan membantu mengatasinya.

2. Pendekatan kelompok, yaitu bimbingan yang diberikan pada kelompok siswa yang melakukan kenakalan. Menurut. Gunarsa (2009:144) bimbingan dapat dilakukanmelalui pendekatan langsung dan pendekatan kelompok.

Kejadian bullying terjadi disebabkan oleh beberapa faktor diantaranya sebagai berikut (Astuti, P, 2008, hlm. 4-5):

1. Perbedaan kelas (senioritas), ekonomi, agama, jender, atnisitas/rasisme.

2. Tradisi seniorotas

3. Senioritas, sebagai salah satu perilaku bullying, seringkali pula justru diperluas oleh siswa sendiri sebagai kejadian yang bersifat laten. Bagi mereka keinginan untuk melanjutkan masalah senioritas ada untuk hiburan, penyaluran dendam, iri hati, atau mencari popularitas, melanjutkan tradisi atau untuk menunjukkan kekuasaan.

4. Keluarga yang tidak rukun.

5. Situasi sekolah yang tidak harmonis atau diskriminatif.

6. Karakter individu/kelompok seperti:

a. Dendam atau iri hati 
b. Adanya semangat ingin menguasai korban dengan kekuatan fisik dan daya Tarik seksual

c. Untuk meningkatkan popularitas pelaku di kalangan teman sepermainan (peer group)nya.

7. Persepsi nilai yang salah atas perilaku korban.

Berbagai macam faktor penyebab anak menjadi bully, hal tersebut diungkapkan oleh orang tua pelaku bully. Diantaranya yaitu karena mereka pernah menjadi korban bullying, ingin menunjukkan eksistensi diri, ingin diakui, pengaruh tayangan televisi yang negatif, senioritas, iri hati, menutupi kekurangan diri, mencari perhatian, balas dendam, iseng, sering mendapat perlakuan kasar di rumah dan dari teman-teman, ingin terkenal dan ikutikutan. (Sejiwa, 2008. Hlm. 16)

Permasalahan dalam dunia Pendidikan tidaklah sedikit sehingga sebagai seorang pendidik harus mampu mengklasifikasi permasalahan yang ada, khususnya pada perilaku bullying di sekolah. Sehingga guru harus mengetahui penyebab perilaku bullying di sekolah diantaranya yaitu: lingkungan sekolah yang kurang baik, senioritas yang tidak pernah diselesaikan, guru yang memberikan contoh kurang baik pada siswa, ketidak harmonisan di rumah, dan karakter anak. (Astuti, 2008, hlm. 52)
Segala upaya dan strategi yang dilakukan oleh guru PPKn SMK 17 Kota Serang dilakukan sebagai upaya pencegahan dan penanganan kekerasan terhadap siswa.

Astuti, P (2008, hlm. 51) mengungkapkan bahwa "dalam mengatasi perilaku bullying pihak sekolah harus mampu mengurangi atau meniadakan tindakan bullying (baik yang dipengaruhi atau dilakukan oleh siswa, guru atau orang tua) dan melihat kembali system Pendidikan dan sosialisasi sekolah serta menyelenggarakan jaringan komunitas sekolah yang efektif.

Sebagaimana yang tercantum dalam permenpppa no.2 Tahun 2010 tentang Rencana Aksi Pencegahan dan Penangan Kekerasan terhadap Anak, pasal 3 bahwa pencegahan dan penanganan kekerasan terhadap anak bertujuan untuk:

a. Menjamin peningkatan, pemajuan, penegakan, pemenuhan, dan perlindungan hak-hak anak untuk dapat terbebas dari segala bentuk kekerasan.

b. Mewujudkan kegiatan baik yang bersifat preventif, promotif, kuratif dan rehabilitatif terhadap anak dari kekerasan; dan

c. Meningkatkan efektivitas pelaksanaan pencegahan dan penanganan kekerasan terhadap anak yang menjadi kewajiban 
kementerian/lembaga

dan masyarakat.

Salah satu upaya yang dapat dilakukan oleh guru menurut Astuti, P (2008, hlm.51) ialah guru mengajak sang pelaku bullying untuk merasakan perasaan sang korban saat menerima perlakuan bullying, tumbuhkan empatinya. Angkatlah kelebihan atau bakat sang pelaku bullying dibidang yang positif yang kita ketahui, usahakan untuk mengalihkan energinya pada bidang positif. Kita mungkin dapat perlahan mengajak pelaku bullying membantu korban mengatasi kelemahan dan kekurangannya. Ini bisa menjadi jalan untuk memberdayakannya dan meningkatkan kepercayaan dirinya.

\section{KESIMPULAN}

Berdasarkan pada temuan data di lapangan dapat diambil kesimpulan berkenaan dengan rumusan masalah yang diangkat dalam penelitian ini. Hal-hal tersebut sebagai berikut :

1. Peran Guru PPKn dalam Mengantisipasi Kekerasan pada siswa di SMK 17 KOTA berperan sebagai pembimbing, sebagai agen moral, sebagai model dan sebagai komunikator dalam kegiatan belajar mengajar sangat diperlukan, selain melaksanakan tugas mengajar, melatih, yang esensial adalah mendidik tingkahlaku siswa supaya tidak melanggar peraturan di sekolah dan mampu mencegah kekerasan pada siswa di SMK 17 kota serang. kekerasan secara generik dipergunakan untuk menggambarkan perilaku menyakiti orang lain baik secara fisik maupun non fisik.

2. Adapun strategi yang dilakukan oleh guru PPKn SMK 17 Kota Serang dalam untuk mengantisipasi kekerasan pada siswa ialah dengan memberikan pemahaman terkait norma norma , Membuat peraturan yang tegas agar siswa tidak melakukan kekerasan, guru meningkatkan komunikasi yang baik dengan siswa, melakukan kerja sama antara guru dan orang tua agar orang tua mengetahui permasalahan anaknya di sekolah agar orang tua bisa memantau perkembangan anaknya.

\section{DAFTAR PUSTAKA}

\section{Buku:}

Amri, Sofan. (2013). Penerapan \& Model Pembelajaran Dalam Kurikulum 2013. Prestasi Pustaka Publisher: Jakarta.

Astuti, P. 2008. Meredam Bullying; 3 Cara efektif menanggulangi 
kekerasan pada anak. Jakarta: PT Grasindo.

Berkowitz, L. . Emotional Behavior Mengenali Perilaku dan Tindakan Kekerasan di Lingkungan Sekitar Kita dan Cara Penanggulangannya. Jakarta: PPM.

Coloroso, B. 2008. Stop Bullying Memutus Mata Rantai Kekerasan Anak dari Persekolahan hingga SMU. Jakarta: Serambi.

Gunarsa, Singgih D. dan Ny. Singgih D. Gunarsa, 2009. Psikologi Perkembangan Anak dan Remaja. Jakarta: PT Gunung Mulia.

Hurairah, A. (2007). Child Abuse (Kekerasan pada Anak) edisi revisi. Bandung : Nuansa

Moh. Roqib dan Nurfuadi. 2009. Kepribadian Guru: Upaya Mengembangkan Kepribadian Guru yang Sehat di Masa Depan. Jogjakarta: Grafindo Litera Media,

Nasution, S. 1998. Metodologi Penelitian Naturalistik Kualitatif. Bandung: Tarsito,
Sejiwa. 2008. Bullying (Mengatasi Kekerasan di Sekolah dan Lingkungan Sekitar Anak). Jakarta: PT Grasindo, Anggota IKAPI.

Sugiyono. 2014. Memahami Penelitian Kualitatif. Bandung: Alfabeta.

Sukardjo, M. dan Ukim Komarudin, 2009. Landasan Pendidikan Konsep dan Aplikasinya. Jakarta: PT Raja Grafindo Persada,

Wiyani, N.A. 2012. Save Pur Children from School Bullying. Depok: ArRuzz Media.

\section{Jurnal}

Hermawati, I dan Sodian, A, 2018. Kekerasan Seksual oleh Anak Terhadap Anak Child on Child Sexual Abuse. Jurnal PKS. Vol.17 (1). HIm 1-20

Yenes, Ilfajri. 2016. "Perilaku Bullying dan Peranan Guru Bk/Konselor dalam pengentasanya." Jurnal Bimbingan Konseling. Vol.5. 1

Luciano, S dan Savage, R. 2007. Bullying Riks in Children with learning difficulties in Inclusive Educational Settings. Canadian Journal of School Psychology. Vol. XX II. 


\section{Peundang-undangan}

Farida Harahap, Kartika Nur Fathiyah, Isti

Yuni Purwanti, Dan Rita Eka Izzaty. 2012.Pengembangan Media Gambar

Undang-Undang Nomor 20 Tahun 2003 tentang Sistem Pendidikan Nasional.

Sebagai Alat Edukasi Antisipasi Diri

Anak Terhadap Perilaku Kekerasan

Fip. Jurnal Kependidikan Penelitian

Peraturan Menteri Negara Pemberdayaan

Inovasi Pembelajaran. Vol 42, No 1.

Perempuan dan Perlindungan anak

Https://Journal.Uny.Ac.Id/Index.Php

/Jk/Article/View/2230

Republik Indonesia Nomor 02

Tahun 2010 tentang Rencana Aksi

Pencegahan dan Penangan

Kekerasan terhadap Anak 